\title{
The Path to Sweet Success: Free and Unfree Labor in the Building of Roads and Rails in Havana, Cuba, I $790-1835^{*}$
}

\author{
EVELYN P. JENNINGS \\ St. Lawrence University \\ Vilas Hall io3, Canton, NY I3617, USA \\ E-mail: ejennings@stlawu.edu
}

\begin{abstract}
Havana's status as a colonial port shaped both its infrastructure needs and the patterns of labor recruitment and coercion used to build it. The port city's initial economic and political orientation was maritime, with capital and labor invested largely in defense and shipbuilding. By the nineteenth century, Cuba had become a plantation colony based on African enslavement, exporting increasing quantities of sugar to Europe and North America. Because the island was relatively underpopulated, workers for infrastructure projects and plantations had to be imported through global circuits of coerced labor, such as the transatlantic slave trade, the transportation of prisoners, and, in the I80os, indentured workers from Europe, Mexico, or Asia. Cuban elites and colonial officials in charge of transportation projects experimented with different mixes of workers, who labored on the roads and railways under various degrees of coercion, but always within the socio-economic and cultural framework of a society based on the enslavement of people considered racially distinct. Thus, the indenture of white workers became a crucial supplement to other forms of labor coercion in the building of rail lines in the i 830 , but Cuban elites determined that these workers' whiteness was too great a risk to the racial hierarchy of the Cuban labor market and therefore sought more racially distinct contract workers after i 840 .
\end{abstract}

\section{INTRODUCTION}

The construction of infrastructure in Cuba, whether for imperial defense or private economic interests, was carried out by a shifting combination of state and local actors, often with motley crews of forced and free laborers. Because Cuba did not have a substantial indigenous population beyond the middle of the sixteenth century, many of the laborers for construction projects were

\footnotetext{
* The author would like to thank Pepijn Brandon, Niklas Frykman, Pernille Røge, Marcus Rediker, and all the participants in the "Free and Unfree Labor in Atlantic and Indian Ocean Port Cities (c.1700-1850)" conference and workshop at the University of Pittsburgh for helpful criticisms and suggestions for revising this essay.
} 
involuntary migrants from Africa or from other regions of the Spanish Empire. In this sense, Havana's port was also the site of first arrival for many of the people who built and labored in the city and extended the empire's economic and political reach into the countryside. The port's infrastructure projects also served as a testing ground for different mixes of forced and free laborers in completing difficult, unskilled work. The consolidation of the social and economic structures of plantation slavery in the first third of the nineteenth century in Cuba framed all later experiments with labor. The experiences of Cuban officials in the road and rail projects from I 790 to i 835 informed their successors' resort to indenture to supplement enslavement in both public and plantation work by the 1840 , and their insistence on maintaining the controls of slavery over workers who were legally freer.

As this brief summary suggests, freedom and unfreedom were not absolute opposites in theory or practice for workers in Cuba in the eighteenth and nineteen centuries. The levels of violence and constraint experienced by the laborers discussed in this essay in the areas of recruitment, compensation, and "control over the working body" demonstrate most clearly the range of coercion that employers applied to workers of varying status in Cuba, from the enslaved and indentured to convicts and to those who were legally free. ${ }^{\mathrm{I}}$ In the context of a society in which enslavement was deeply embedded and expanding, employers sought to extend the controls applied to slaves shackles and chains, the lash, and the barracoon - to workers who were not enslaved by law, though workers' resistance did limit the success of these efforts. At this time, Spanish law defined "free" persons as those not bound by the strictures of slavery, by which another person owned both the slave's body and labor, or by a judicial sentence or contract to labor for a given period. This essay seeks to illuminate the many ways that both the free, the enslaved, and those in between in colonial Cuba were subject to violence and coercion as part of their work for the state. Thus, the terms free and unfree highlight the contingent and broad nature of both categories in the work regimes imposed on laborers in road and rail projects of colonial Cuba.

\section{FROM IMPERIAL SERVICE TO PLANTATION EXPORT}

For the first two centuries of colonial rule, Havana's orientation and connections were largely maritime. Goods, capital, and labor arrived from other Spanish Caribbean ports such as Cartagena de Indias or Veracruz, or from the metropole across the Atlantic. The Spanish Crown sought to control imperial trade and migration to the island by funneling it through designated 
ports such as Seville and later Cádiz, and Veracruz. However, unlike many other colonial ports in Spain's American empire, initially Havana's primary function was not to be an outlet for goods produced in Cuba. Rather, as historian Alejandro de la Fuente has noted, "it was the port that made the hinterland", though this process was a slow one. ${ }^{2}$

Havana became the gathering site for the convoys returning to Spain in the I 550 and maintained that role into the late eighteenth century. Infrastructure investment around the port by the crown from the late i 500 s to the $1700 \mathrm{~s}$ focused on securing the city and its bay with forts and a wall to deter pirate or imperial rivals' attacks from the sea. In addition, the vast majority of the people who built and sustained the city and its port also arrived by sea or were descended from those who had done so, making Havana a diverse and cosmopolitan place even in its first century as a Spanish colonial port. ${ }^{3}$

Unlike other Caribbean colonies such as Barbados or Saint Domingue, the Havana region developed into a major producer of tropical products for export only after 1750, recasting the port's role in the empire and its infrastructure needs. ${ }^{4}$ Though the port's maritime connections continued to be vital and expand throughout the eighteenth and nineteenth centuries, by the 1790 s the orientation of infrastructure investment shifted inward to extend a network of roads, and later rails, to link Havana's widening plantation hinterland to its port to ensure the transport of sugar and coffee to overseas markets.

Cuba's shift to slave-based plantation production also transformed its demography as the white population was overshadowed by a rapidly growing enslaved and free population of African descent in the first third of the nineteenth century. Enslavement and other forms of forced labor were longstanding practices of conquest and colonization in the Spanish Empire. Though full-blown plantation economies were a late development, the execution of defense works for the key imperial ports such as Havana often relied on coerced laborers. ${ }^{5}$ For example, by the eighteenth century, as the Spanish monarchy contended with growing French and English power in the Americas, the Spanish crown expanded its use of state-owned enslaved workers to better fortify Cuba after the British occupation of Havana ended in 1763. Over the next three decades, colonial officials on the island also

2. Alejandro de la Fuente, Havana and the Atlantic in the Sixteenth Century (Chapel Hill, NC, 2008), p. 9.

3. Ibid., p. 6.

4. Allan J. Kuethe, "Havana in the Eighteenth Century", in Franklin W. Knight and Peggy K. Liss (eds), Atlantic Port Cities: Economy, Culture, and Society in the Atlantic World, I650-1850 (Knoxville, TN, I991), pp. I3-39.

5. Evelyn P. Jennings, “The Sinews of Spain's American Empire: Forced Labor in Cuba from the Sixteenth to the Nineteenth Century", in John Donoghue and Evelyn P. Jennings (eds), Building the Atlantic Empires: Unfree Labor and Imperial States in the Political Economy of Capitalism, ca. I500-I9I4 (Leiden, 20I6), pp. 25-53. 
experimented with ways of forcing legally free people to do defense and civil construction and to serve in the military through levies during the revolutionary era in the Caribbean. ${ }^{6}$

For Cuba, militarization and state investment in defense were coupled with Crown concessions to liberalize trade and state-private efforts to foment economic development. By the time slave rebellion in nearby Saint Domingue had destroyed that island's booming planation sector, Cuba was poised to take its place. Hence, the period from $\mathrm{I} 790$ to $\mathrm{I} 840$ saw major transformations in Cuba as elites and colonial officials collaborated to foster plantation development and to better defend the island. At the heart of these transformations was the shift in the island's economy from imperial service to plantation production of coffee and sugar for export. ${ }^{7}$ This transformation was demographic and geographic; plantations spread out from the Havana region into new parts of the island, creating explosive demand for enslaved workers. This demand for labor and the relaxation of imperial controls on the slave trade brought more than 536,000 enslaved Africans to Cuba over the fiftyyear period. ${ }^{8}$

These demographic transformations prompted concerns among the Cuban elite about the "Africanization" of the island's population, particularly in light of the revolutionary upheaval in Saint Domingue that culminated in the declaration of a black republic in $1804 .{ }^{9}$ Proposals debated over the next forty years all sought to increase white migration to Cuba, though members of the elite differed over whether continuing the importation of African slaves was wise. The proponents of white immigration also differed on whether to recruit white families with offers of modest plots of land for farming or single white men to work for a wage on plantations. ${ }^{\circ}{ }^{\circ}$ How best to increase the numbers of available laborers in Cuba for both statesponsored projects and agriculture remained a challenge throughout the first half of the nineteenth century, but there was little debate about the desirability of increasing sugar production to fill the void left in the world's supply after the collapse of Saint Domingue. The experiments to recruit labor for

6. Evelyn P. Jennings, "War as the 'Forcing House of Change': State Slavery in Late-EighteenthCentury Cuba", William and Mary Quarterly, 62:3 (2005), pp. 4I I-440.

7. For a more recent examination of these transformations, see Ada Ferrer, Freedom's Mirror: Cuba and Haiti in the Age of Revolution (New York, 2014). The classic and still indispensable work is Manuel Moreno Fraginals, El ingenio. Complejo económico social cubano del azúcar (Barcelona, 200I [1978]).

8. Derived from the Transatlantic Slave Trade Database: Cuba/disembarkation/ I790-1 840 , available at: http://www.slavevoyages.org/estimates/oCxkiQIw; last accessed ı० February 2018. 9. Consuelo Naranjo Orovio, "La amenaza haitiana, un miedo interesado: poder y fomento de la población blanca en Cuba", in María Dolores González-Ripoll et al. (eds), El rumor de Haití en Cuba: Temor, raza y rebeldía, 1789-I844 (Madrid, 2004), pp. 83-99. See also Ferrer, Freedom's Mirror.

ı०. Naranjo Orovio, "La amenaza haitiana", pp. IOI-178. 
infrastructure projects informed and were informed by the consolidation of plantation slavery in Cuba. Elites were particularly concerned about where a given group of workers would fit in the racial hierarchy and whether the costs to recruit, maintain, and control those workers were sustainable.

In addition to recruiting labor, the geographic expansion of plantations necessitated the construction or repair of roads to ensure the efficient transport of export products to the port of Havana, especially for the more perishable export, sugar. Into the eighteenth century, road building and repair had been carried out by private householders in the countryside, employing local, free, and enslaved laborers. Many travelers to Cuba reported on the disastrous state of its roads, especially during the rainy season. The most famous traveler of the early nineteenth century, Alexander von Humboldt, noted from his visits in $1800-180 \mathrm{I}$ and I804 that the streets of Havana were "disgusting [...] because one walked up to the knees in mud". Roadways leading out of the capital were no better as "[ $t]$ he interior communications of the island [were] laborious and costly, in spite of the short distance [...] between the northern and southern coasts". ${ }^{\text {II }}$ Decades of local efforts brought little progress in road repair and construction, as weather and wear took their toll. Von Humboldt favored the digging of a canal to improve north-south transport, but this project never came to pass. ${ }^{\text {I2 }}$

After an intense period of the colonial state employing enslaved and other coerced workers to build and repair the defense works of Havana (1763I790), Crown officials, many of whom had become planters themselves, began to intervene to speed road construction and repair to outlying plantation districts. Initially, the captains general tried to encourage, then force, free householders to do the work of road and bridge construction themselves, with scant success as many claimed their military service as grounds for an exemption from road work. ${ }^{13}$ The failure to coerce local free people to extend the road network stimulated Cuban elites and colonial officials to explore other options. By the I790s, wealthy creole planters petitioned the Spanish Crown for control of the labor of captured fugitive slaves to advance road construction, again with only limited success. Finally, the obstacles to transportation construction were overcome by recruiting contract laborers abroad and undermining the liberty of Africans freed by British anti-slave trade treaties to build the first rail line in Latin America, from Havana south and east to Güines; the line was finished in $1838 .{ }^{\mathrm{I}}$

I I. Alexander von Humboldt, Ensayo politico sobre la isla de Cuba (Madrid, I998 [1827]), pp. 108 and 273. The translations from the Spanish are my own.

I2. Von Humboldt, Ensayo político sobre la isla de Cuba, pp. 273-276.

I 3. Sherry Johnson, The Social Transformation of Eighteenth-Century Cuba (Gainesville, FL, 200I), pp. I $2 \mathrm{I}-\mathrm{I} 45$.

I4. These liberated Africans were often called emancipados in Cuba. Inés Roldán de Montaud, “Origen, evolución, y supresión del grupo de negros 'emancipados' en Cuba i817-1870", 
Thus, capitalist development of the export economy in Cuba was closely intertwined with the imperial state's policies and practices of labor recruitment and deployment in public works. The state and its contractors sought to hold down labor costs and exert control over workers' mobility and pace of work by experimenting with a range of coercive labor forms, such as enslavement, penal labor, and apprehensions of vagrants and fugitive slaves. The analysis here shows that the experiments with varied types of forced labor that successfully completed road and rail networks shaped later labor experiments on plantations, when African slavery was disrupted by the long process of abolition in the Atlantic world.

\section{COLONIAL PRECEDENTS IN LABOR RECRUITMENT} BEFORE THE I 790 s

Much of the colonial infrastructure of Havana was built with combinations of forced and free labor. The construction of the earliest forts to guard the port employed state- and privately owned slaves, prisoners, and free workers from the local population, Africa, and Europe. ${ }^{\mathrm{IS}}$ By the mid-eighteenth century, as the city's strategic importance to the empire grew, the Spanish Crown subsidized Havana's defenses with Mexican silver and increasing numbers of forced laborers, both slaves and convicts, employed in defense works.

The height of the use of state slavery for Havana's defense works came immediately after the British occupation of Havana in 1762 . The Spanish Crown purchased over 4,000 African slaves in the king's name to build and repair its fortifications. The costs of maintaining such a large cohort of state slaves quickly led the Crown to reduce their numbers and supplement them with more imperial prisoners, mainly those sent from Mexico to the forts of Havana as part of their sentence. ${ }^{16}$

Revista de Indias, 42:169-170 (1982), pp. 574-576; Luis Martínez-Fernández, "The Havana Anglo-Spanish Mixed Commission for the Suppression of the Slave Trade and Cuba's Emancipados", Slavery E Abolition, I6:2 (1995), pp. 209-213. For the experiences of liberated Africans in the British Caribbean, see Rosanne Marion Adderley, New Negroes from Africa: Slave Trade Abolition and Free African Settlement in the Nineteenth-Century Caribbean (Bloomington, IN, 2006).

i 5. De la Fuente, Havana and the Atlantic, pp. 5, 70-71; Reneé Méndez Capote, Fortalezas de la Habana colonial (Havana, 1974).

I6. Jennings, "War as the 'Forcing House of Change”, pp. 4I I-440; Francisco Pérez Guzmán, La Habana clave de un imperio (Havana, I997); Jorge L. Lizardi Pollock, "Presidios, presidiarios, y desertores: Los desterrados de Nueva España, I777-1797”, in Johanna von Grafenstein (ed.), El Caribe en los intereses imperiales, I750-I8IS (San Juan Mixooc, 2000), pp. 20-45; Ruth Pike, "Penal Servitude in the Spanish Empire: Presidio Labor in the Eighteenth Century", Hispanic American Historical Review, 58:1 (1978), pp. 21-40; Christian G. De Vito, "Connected Singularities: Convict Labour in Late Colonial Spanish America (I760sI 800)", in C.G. De Vito and Anne Gerritsen (eds), Micro-Spatial Histories of Global Labour 
The Crown's efforts to better defend Havana and wage war over the eighteenth century brought more Spanish troops to the city, increasing concerns about the disorderly behavior and desertion of military men and others. ${ }^{17}$ Colonial officials also faced the devastation of recurring hurricanes, which damaged roads and bridges with frustrating regularity. ${ }^{18}$ The exigencies of wartime and environmental disasters resulted in greater state intervention in infrastructure projects, particularly in the recruitment and coercion of labor. With Crown support, colonial officials expanded the definitions of vagrancy and even resorted to forced levies to keep order and complete the port's defense works during the cycles of Caribbean warfare in the late i700s. ${ }^{19}$

In a series of royal orders over the eighteenth century, the Spanish Crown defined more clearly the category of vagrant and its negative connotations. A royal order from 1717 defined those who could be subject to levies of vagrants as "bad living people" with "no honor". ${ }^{\circ}$ By 1745 , the Crown had issued another order that expanded its definition of vagrancy and delinquency to cover all who had no trade, home, or income, and lived "not knowing from what licit and honorable means their subsistence might come". ${ }^{2 \mathrm{I}}$ The order included both the unemployed and the underemployed who did not find productive activities to occupy their time during dead seasons. The delinquent included gamblers, drunks, the sexually promiscuous or adulterous, pimps, and disobedient children. Crown officials also distinguished between "deserving" beggars, who merited compassion and charity, and "false", able-bodied beggars, who were to be prosecuted as vagrants. ${ }^{22}$

The metropolitan approach also revealed a growing effort to centralize the holding of captured vagrants under royal control and to harness their labor. In the I730s and I740s, the Crown ordered that vagrants be detained and

(New York, 2018), pp. I7I-202; Jason M. Yaremko, Indigenous Passages to Cuba, I5I5-1900 (Gainesville, FL, 20I6), pp. 66-79.

17. On the militarization of Cuba after 1763, see Allan J. Kuethe, Cuba, 1753-I8I5: Crown, Military, and Society (Knoxville, TN, 1986), and Johnson, Social Transformation.

I8. On the interactions of cycles of storms and droughts with warfare and revolution in the eighteenth-century Spanish Caribbean, see Sherry Johnson, Climate and Catastrophe in Cuba and the Atlantic World in the Age of Revolution (Chapel Hill, NC, 201 I).

19. On sweeps of Havana that netted men for Spanish ships stationed there, see Josef Solano to Juan Manuel Cagigal, 8 January 1782, and Juan Manuel Cagigal to José de Gálvez, 20 February I782, Archivo General de Indias [hereafter, AGI], Santo Domingo [hereafter, SD], legajo [hereafter, leg.] I 234, no. I 80 . On the Spanish state's increasing preoccupation with vagrancy, see Rosa María Pérez Estévez, El problema de los vagos en la España del Siglo XVIII (Madrid, I976), and in Cuba, Juan B. Amores, Cuba en la época de Ezpeleta (1785-I790) (Pamplona, 2000), pp. I I7-1 23. 20. Royal Order, 2 I July I717, quoted in Pérez Estévez, El problema de los vagos, p. 61.

21. Royal Order, 30 April 1745 , quoted in Pérez Estévez, El problema de los vagos, p. 6 I.

22. Pérez Estévez, El problema de los vagos, pp. 56-8 I. Similar characterizations were articulated and drove policy in late eighteenth-century Mexico. See Silvia Marina Arrom, Containing the Poor: The Mexico City Poor House, I774-I87I (Durham, NC, 200I), p. 23. 
held in jails, sending the able-bodied among them to army service or public works. In I775, Charles III authorized annual levies to round up vagrants, and in the later I 770 s shelters were established in Madrid to hold them. In 1779, when Spain joined France to intervene in the American War of Independence, the king set the term of service at eight years for captured vagrants sent to the army. The Crown continued to publish bans against vagrants, beggars, and foreigners every few years over the next two decades. ${ }^{23}$

In Cuba, colonial officials employed metropolitan directives to extend their authority out from Havana into the countryside. Before 1762 , the deputizing of patrols to track down enslaved fugitives and military deserters had rested with the local town governments, but this power was appropriated in moments of crisis. For example, in 1765 , Captain General Ricla created a rural police and judiciary force that reported directly to him and the captains of partidos (districts of the interior). ${ }^{24}$ As the Captain General's representatives in the countryside, the captains of partidos were charged with maintaining good order and seeing to the needs of the local population. After a terrible hurricane in 1768, Captain General Bucareli also sent out groups of soldiers to round up escapees. The king ordered that those apprehended as vagrants be employed in Crown projects or on public works, or be exiled from Havana altogether. ${ }^{25}$

Times of emergency allowed the colonial state to extend its power and create new corps to enforce that power. Once extended, the state rarely returned power to the localities. Still, as historian Sherry Johnson has argued, for several decades after the British occupation the governors in Havana maintained a reputation for good government, at least with the "better" classes, through their attention to the public welfare during disasters, which helped justify and control resistance to their extension of power. ${ }^{26}$ The constant stream of desertions and reports of delinquency from the captains of partidos suggests that many of those pressed into military service or defense construction were less appreciative. ${ }^{27}$

Bucareli's successor as Captain General, the Marqués de la Torre (I77I-I777), enjoyed a brief respite from warfare and was able to perfect the mechanisms of capture and deployment of a range of transgressors to

23. Luis Miguel Enciso Recio, "Prólogo", in Pérez Estévez, El problema de los vagos, pp. i6-17, lists bans published in Madrid on vagrants, the idle poor, and foreigners in $1783,1786,1789$, I790, I79I, and 1798 .

24. Juan B. Amores Carredano, "Ordenanzas de gobierno local en la isla de Cuba ( $1765-1786)$ ”, Revista complutense de Historia de América, 30 (2004), pp. 95-109.

25. "San Lorenzo, 19 de Noviembre de $1769=$ Yo El Rey", Escoto Collection, Houghton Library, Harvard University, bMS Span 52, 858. Johnson, Crisis and Catastrophe, p. 88.

26. Johnson, Crisis and Catastrophe, ch. 4, pp. 92-1 22.

27. See, for example, Amores, Cuba, pp. I17-120, on the mid-i 780 s. 
carry out a major program of urban renewal that included street paving in Havana and the building of bridges on thoroughfares out of the city. To stem the tide of military desertions and flight from work sites, De la Torre established both uniformed and plain-clothes (disfrazados) patrols to search for fugitives, centralizing some components of the apprehensions begun under his predecessors. ${ }^{28}$ Captors notified the Captain General of an apprehension and requested reimbursement for maintenance costs, transport, and fees. ${ }^{29}$ His office began keeping track of the deserters recaptured in 1775 , reporting a total of sixty-four rounded up by the end of his term in I777..$^{\circ}$ The growing size and complexity of Havana, in both its spatial and human dimensions, spurred De la Torre and his successors to expand the state's powers of coercion to control the swelling numbers of people trying to escape military service or the more restrictive norms of decent behavior, with the approval of Cuban elites.

When De la Torre turned over the reins of government to his successor Diego Navarro in $\mathbf{1 7 7 7}$, he highlighted his efforts at improving policing to ensure the "tranquility and good order" of Havana and its benefits in recruiting labor for public works. ${ }^{3 \mathrm{I}} \mathrm{He}$ claimed to have sent 8,263 people to jail in less than six years, though most spent little time behind bars because the usual punishment was to "send them to public works for more or less time according to the crime". ${ }^{32}$ Colonial officials scrambled to find labor for fort projects in the 1760 s and had looked outside Cuba for forced labor - purchasing the king's slaves in the mid-I760s - and then shifted to requesting more imperial convicts from Mexico. While De la Torre continued to use both state slaves in smaller numbers and convicts to finish defense works, he turned the state's coercive power on the island population to find labor for civil construction projects in the I770s. His successors continued to persecute and prosecute the "vice-ridden and evilly entertained", but found diminishing returns with this policy for staffing road-building projects.

28. El Marqués de la Torre, “Apuntes de las principales providencias”, Del Monte Collection, Manuscript Division, Library of Congress [hereafter, LOC] (Havana, I I June I777), Box 3, nos 3-4, fos 2-3.

29. See AGI, Papeles de Cuba, leg. i I 53 , for numerous examples.

30. "Cargos y Esculpaciones del Sr. Mqs de la Torre", Archivo Histórico Nacional [hereafter, AHN], Consejos, 20892, 2 a (Havana, 25 October 1777), fo. 195.

31. For descriptions of civil projects completed during De la Torre's term in office, see Miguel Josef de Azanza, "Noticia formada de orden del Señor Marqués de la Torre, Gobernador y Capitán General de la Isla de Cuba, de los caudales que se han invertido en la Havana y sus cercanías, y de los repartimientos y arbitrios que los han producido", AHN, Consejos, 20892 6a (Havana, I 2 April 1777), fos 30-36.

32. De la Torre, "Apuntes sobre las principales providencias", Del Monte Collection, Manuscript Division, LOC, Box 3, no. 4, fos $2-3$. 
During the years of Spain's intervention in the American War for Independence (I779-I783), the captains general of Cuba resorted to levies on the free population to recruit troops for the army and navy and laborers for defense works. ${ }^{33}$ Many free people, both white and of color, also volunteered for militia service during the war. The end of hostilities in 1783 found much of the Cuban population exhausted after the considerable sacrifices demanded by the war effort; this complicated the search by state officials for labor to build and repair roads.

\section{PRESSURE ON FREE PEOPLE FOR ROAD WORK}

The captains general who served from the mid-I780s to the mid-I790s found free Cubans less willing than they had been in the late 1760 s and 1770 s to volunteer for road construction. Of particular concern were the roads and bridges to the south and east of Havana toward Güines and Matanzas, where some of the greatest sugar and coffee expansion was concentrated. Even before the revolution in Saint Domingue in 179I opened greater opportunities for Cuban planters in the world market, sugar production had begun to grow substantially. Sugar exports through Havana doubled in the decade from 1776 to 1785 , then more than doubled again between 1785 and 1800 . By i 840 sugar exports from Havana had reached 26.6 million arrobas, an almost twelvefold increase (Table i).

Already by the mid-1780s, colonial officials were meeting resistance in recruiting labor for road and bridge works, though some progress was made by sending out groups of coerced workers in the state's charge to the projects. Captain General Ezpeleta ( $1785-1790)$ sent numerous requests to his captains of partidos in the region to require local householders (vecinos) to give two days per week to road and bridge building and repair or to send several slaves or farmhands in their stead. He often received long reports of reasons why local vecinos could not or would not comply, particularly from those whose military privileges freed them from labor in public works. To advance the road projects, Ezpeleta gave the contractor in charge of the works access to a number of captured deserters, fugitive slaves, and escaped convicts. Ultimately, this infusion of forced laborers had some success in improving the road networks between Havana and the growing

33. For example, in $178 \mathrm{I}$, Captain General Juan Manuel de Cagigal rounded up men to serve in his expedition the following year against Providence Island in the Bahamas. Antonio J. Valdés, Historia de la Isla de Cuba, y en especial de la Habana, 2 vols (Havana, I8 I 3), I, p. I92. On sweeps of Havana that netted men for Spanish ships stationed there in this same period, see Josef Solano to Juan Manuel Cagigal, 8 January 1782, and Juan Manuel Cagigal to José de Gálvez, 20 February 1782, AGI, SD, leg. I234, no. I 80. 
Table I. Sugar exported from Havana $1776-1840$ in arrobas.

\begin{tabular}{lr}
\hline Five-year intervals & Sugar exports \\
\hline $1776-1780$ & $2,295,456$ \\
$1781-1785$ & $4,939,984$ \\
$1786-1790$ & $5,191,552$ \\
$1791-1795$ & $6,718,416$ \\
$1796-1800$ & $11,008,144$ \\
$1801-1805$ & $14,253,040$ \\
$1806-1810$ & $14,090,704$ \\
$1811-1815$ & $13,327,728$ \\
$1816-1820$ & $16,544,360$ \\
$1821-1825$ & $20,031,424$ \\
$1826-1830$ & $20,988,495$ \\
$1831-1835$ & $21,877,219$ \\
$1836-1840$ & $26,606,316$ \\
\hline
\end{tabular}

Sources: Pablo Tornero Tinajero, Crecimiento económico y transformaciones sociales: esclavos, hacendados, y comerciantes en la Cuba colonial (1760-1840) (Madrid, 1996), Appendix 3, p. 383, for 1776-1820 and 1826-1840; Von Humboldt, Ensayo politico, p. 218, for 1821-1825.

plantation areas in the second half of the 1780 s. ${ }^{34}$ Ezpeleta's successor was not so fortunate.

In the summer of 1790 , Luis de Las Casas arrived in Cuba as the new Captain General and a dedicated supporter of sugar expansion. Plantation owners sought to ensure his long-term favor by presenting Las Casas with a plantation of his own, complete with machinery and enslaved laborers. ${ }^{35}$ One way that Las Casas sought to reward their generosity and reap the maximum benefit from his plantations was to advance the road-building projects. He had an ambitious plan to connect Havana to other Cuban ports by land, with trunk lines to the port of Matanzas to the east and Batabanó to the south, as well as roads to inland regions with essential timber and plantation products such as Güines. ${ }^{36}$

Las Casas began his road building program with an order in late $\mathrm{I} 790$ for all able-bodied men to report for road work. Almost immediately, captains of partidos began reporting resistance, such as an unruly crowd in a small town southeast of Havana refusing to report for road duty. The ringleaders were sent to Havana for a personal admonishment by the Captain General, who

34. Amores, Cuba, pp. 405-408.

35. It was illegal for Las Casas to own plantations in his own name, so they were registered to others, but he soon purchased a second plantation that grew to be one of the largest in Cuba. Ferrer, Freedom's Mirror, pp. 29-3 I.

36. Las Casas, "Plan de Caminos", Mapas y Planos, Santo Domingo, 583, reproduced in Johnson, Social Transformation, p. I 3 I. 
warned them to respect the authority of their local captains of partidos. ${ }^{37}$ Las Casas continued to press the captains of partidos to force locals to do road work, but vecinos claimed military privileges, illness, and even bad roads as reasons why they could not comply. ${ }^{38}$ In short order, even the government's representatives in the countryside joined the effort to resist the Captain General's orders for free vecinos to perform road work. When pressed by Las Casas to produce workers, town mayors and some of the captains of partidos themselves responded with excuses or not at all. ${ }^{39}$

A severe hurricane in I79I caused extensive loss of life and washed out bridges and roads, but further orders from Las Casas to round up the "idle" and "evilly entertained" yielded few laborers. When the Captain General ordered the captains of partidos to conduct censuses of their jurisdictions' population, several submitted drastically reduced numbers or tried to resign their posts. Las Casas then tried to arrest resisters, putting some in stocks as an exemplary punishment or sending them to road projects as prisoners. Ultimately, the Captain General failed to win the compliance of his underlings or the people they were supposed to recruit. By October 1796, he had admitted defeat on advancing road projects with free laborers and was recalled to Madrid. ${ }^{\circ}$

\section{EXPERIMENTS WITH CAPTURED FUGITIVE SLAVES}

Las Casas's failure to compel free people to do road work necessitated finding other groups of people with fewer ways to resist. The demographic transformation of the Havana region with the influx of thousands of enslaved Africans provided a new group that could be coerced by the state for road work. Captain General Las Casas worked with Havana-area planters through quasi-governmental organizations to advance their mutual interests in road expansion. Organizations such as the Havana Consulado brought together wealthy planters and merchants with colonial officials to foment plantation development and adjudicate commercial disputes. The Consulado also became a new vehicle through which to execute infrastructure projects. ${ }^{4 \mathrm{I}}$

37. Johnson, Social Transformation, p. I 30 , describes a rowdy demonstration that turned hostile to the captain of partido in the town of San José de las Lajas.

38. Amores, “Ordenanzas”, p. I०4; Johnson, Social Transformation, p. I28.

39. Johnson, Social Transformation, p. I 30.

40. Ibid., pp. I37-145.

4I. Its full title was the Real Consulado de Agricultura y Comercio de la Habana. See Peter J. Lampros, "Merchant-Planter Cooperation and Conflict: The Havana Consulado, I 794-I 832" (Ph.D., Tulane University, I 980). For a report on the state of Cuba's roads and possible sources of funding for their repair, see AGI, Ultramar, leg. 170, and Nicolas Calvo y O’Farrill, “'Memoria sobre los medios que convendrá adopter para que tuviese La Havana los caminos necesarios'. Presentada al Consulado por la diputación que con este objeto nombró”, 
In the wake of the slave rebellion in Saint Domingue, planter members of the Consulado, Joseph Manuel de Torrontegui and Francisco Arango y Parreño, proposed to the Crown the centralization of the capture and warehousing of fugitive slaves as a necessary security measure and a remedy for the challenges of recruiting laborers for road work. Showing parallels to state policies of the previous twenty years centralizing the disposition of military deserters, Torrontegui and Arango suggested that the Consulado regulate expeditions of capture and control the disposition of fugitive slaves thereafter..$^{2}$ Their report asked the king to allow all captured fugitive slaves to be assigned to public works and to remain in that service without time limit, unless the owner came forward and could pay the costs of the slave's capture. ${ }^{43}$ In late 1796 , the king agreed and the Consulado became the major beneficiary of their labor on the island. ${ }^{44}$

In spite of having a reasonably low-cost group of laborers at its disposal, the Consulado was not successful in greatly expanding the road system of Cuba over the next thirty-five years. The perennial problem of torrential rains and geographically scattered sites bedeviled the Consulado's projects, such that only 25.4 kilometers were completed by $183 \mathrm{I} .{ }^{45}$ In contrast to the road-building projects of the 1830 s and 1840 s, in the expanding British Empire in Asia discussed in Clare Anderson's essay in this Special Issue, by the mid-nineteenth century the shrinking Spanish Empire did not have significant cohorts of convicts to transport to Cuba for such projects. Dramatic improvements in internal transport in Cuba had to await the construction of railroads in the late 1830 and the resort to coerced laborers from beyond the island and the empire.

Biblioteca Nacional de España [hereafter, BNE], VE I233-I4 (Havana, I795). For the Torrontegui and Arango report see "Informe que presentó en 9 de Junio de 1796 a la Junta de Gobierno del Real Consulado de Agricultura y Comercio de esta ciudad e isla cuando examinó la mencionada Real Junta el Reglamento y Arancel de capturas de esclavos cimarrones y propuso al Rey su reforma”, BNE, s (Havana, I796).

42. Torrontegui and Arango, "Informe", pp. I I-I4.

43. The report's authors did not think the slave owner should have to pay for the slave's maintenance when under the charge of the Consulado, only for the slave's maintenance and transport to Havana, but nor did they think that the Consulado should have to pay wages to the owners for the public labor of their slaves. Ibid., p. 28.

44. The registers of the Havana Depósito, which housed the captured runaways, show almost I6,000 fugitive slaves entered there between 1797 and I8 I 5 . The Depósito program was reasonably effective in eventually returning fugitive slaves to their owners, with eighty-six per cent of the fugitives $\left(\mathrm{I}_{3}, 80 \mathrm{I}\right)$ being returned over the first eighteen years. Even though this group of laborers was not a static and permanent labor force, in a given year the Consulado had at its disposal the labor of hundreds of fugitive slaves for whom it had to pay only the cost of capture and maintenance. Gabino La Rosa Corzo, Los cimarrones de Cuba (Havana, 1988), p. 34 .

45. Ibid., p. I49. 


\section{EXPERIMENTS WITH EMANCIPADOS AND CONTRACT LABORERS}

The Cuban railroad-building projects of the mid-nineteenth century show well the patterns of coercion that were most successful for infrastructure building in Cuba. Unlike railroad building in other colonial settings, the main actors in organizing the first rail project included Havana-dwelling Cubans who also owned plantations outside the city. These planters used their connections in Europe and North America to find the necessary capital, technology, and skilled and unskilled labor to build the first rail line to the growing sugar area of Güines, southeast of Havana.

Though there was a growing enslaved population, high slave prices privileged their employment in the most profitable sectors of the economy. Relatively high wages in other sectors and miserable working conditions on rail projects kept most free workers from choosing labor in public works. Additionally, similar to planters in the private sector, the railroad projects' promoters had to recruit labor in a vastly different labor market from I 820 onward. Anti-slave trade treaties with Great Britain in I8I7 (taking effect in I 820) and 1835 succeeded in disrupting the flow of African slaves to Cuba and raising prices. Spain abolished slavery in the metropole in I 836 and the British officially emancipated the slaves in their empire by I 838 , causing Cuban slave owners to fear the eventual end of slavery on their island as well. ${ }^{46}$ Colonial officials began to experiment with contract labor in the 1830 s to ensure lower costs and sufficient work discipline to complete the first railroad line in Cuba. Their experiments with contract labor for infrastructure building were adapted to the needs of the plantation sector less than twenty years later, as legal access to enslaved workers from Africa through the transatlantic slave trade contracted by the late i 840 s.

The labor force for building the first rail line out of Havana into its hinterland came to include virtually every kind of forced and free laborer ever employed in the colony. The work, similar to plantation labor, fort building, and road work, was arduous and largely unskilled labor, rarely attracting free laborers at the low wages the promoters were willing to offer. An i 837 report from the commission that oversaw the first rail project, lamented that, in Cuba, where "daily wages are so high and hands always scarce for the urgent work of agriculture, workers are not to be found". ${ }^{47}$ From I 835 to I 838 the rail line's workforce contained some slaves owned by or housed in the Havana Depósito for runaway slaves and the nominally free Africans 
Free and Unfree Labor in the Building of Havana's Roads and Rails I63

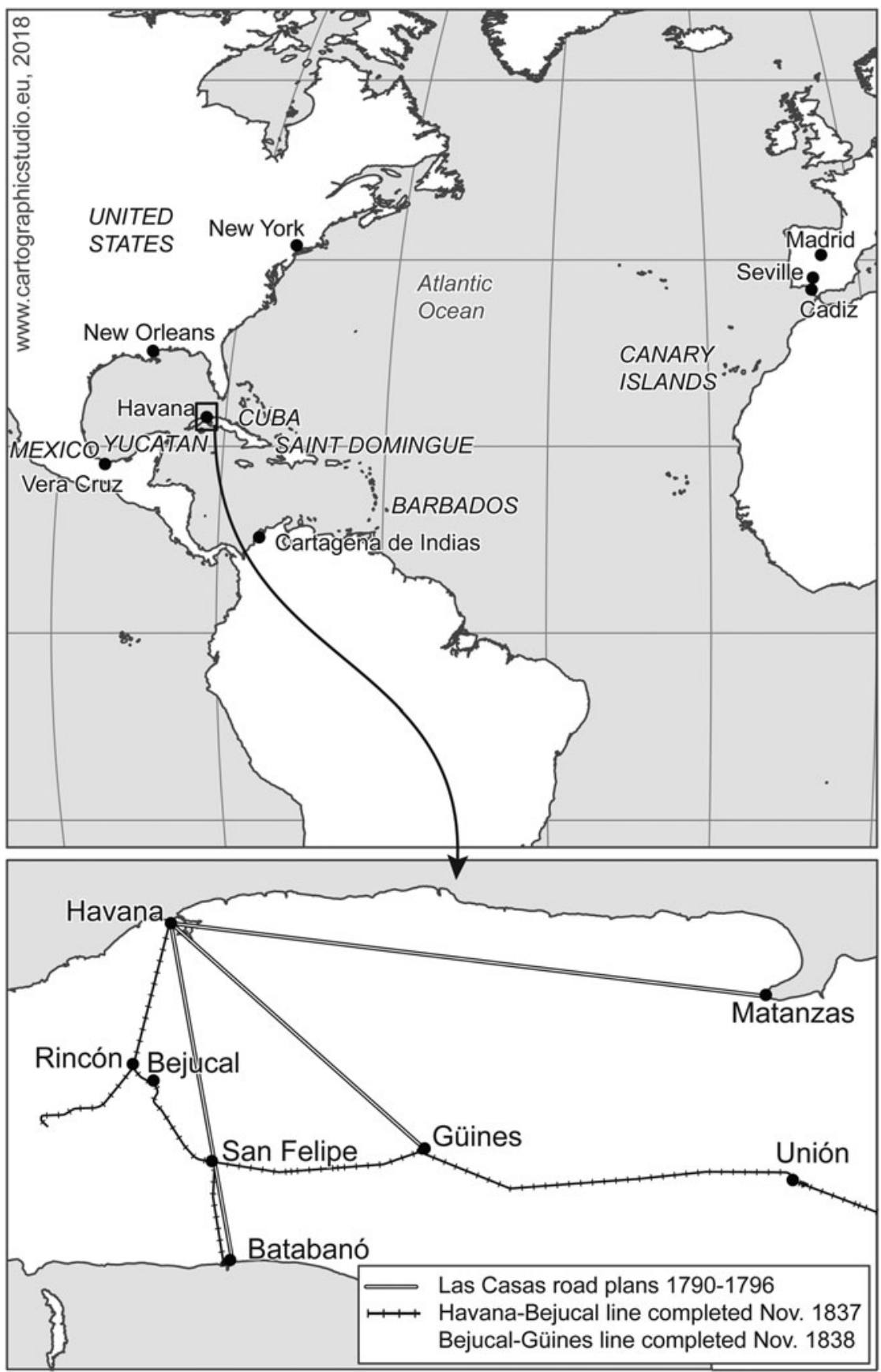

Figure I. Roads Proposed and Rail Lines Built, Havana Region, I790-1 850. 
known as emancipados. ${ }^{4}$ Similar to the labor crews discussed in Martine Jean's essay on the building of the Casa de Correção in Rio de Janeiro in the same period, the British efforts to end the transatlantic slave trade generated a new group of laborers who were legally free but suffered virtual re-enslavement in areas such as Cuba and Brazil, where slavery was not abolished until I 886 and I 888 , respectively. Other workers on the rail projects were convicts - Cubans or criminals sentenced to the island from other parts of the empire. The composite group of forced laborers numbered about 500 per year over the three-year span. ${ }^{49}$

Though some state-owned and captured fugitive slaves and hundreds of emancipados were assigned to the railroad project, the demands of other public works, like road repair, and the 209 deaths among rail workers necessitated a search for new alternatives to recruit workers, while retaining mechanisms of control..$^{\circ}$ Although there had been discussion since at least the late eighteenth century of encouraging white immigration to Cuba, the railroad commission's contracts were the first large-scale initiatives in that direction. ${ }^{5 \mathrm{I}}$

When the Consulado's development board, the Junta de Fomento, contracted engineers Alfred Cruger and Benjamin Wright Jr. from the United States, it empowered them to recruit between 800 and I,200 workers with some construction experience who might be idle during the winter months in New York. The Junta also allowed for the recruitment of overseers who would form their own crews. Wright used established networks in the United States to contract with workers, some of whom had labored there in canal building. Working through the Spanish consul in New York, Francisco Stoughton, the Junta made contracts with overseers, who paid their crews and promised to finish specific portions of the rail line. ${ }^{52}$ One such contractor, John Pascoe, brought along his wife and two children. ${ }^{53}$

48. The emancipados were enslaved Africans freed by the terms of the anti-slave trade treaty signed by Spain and Great Britain in I8I7. After I820, any Africans illegally shipped to Spanish colonies could be seized by the British navy, then freed. In an example of creative coercion by the Spanish state, beginning in I824 the emancipados were consigned to the captains general of Cuba to be allocated to private individuals for training and Christianization rather than returned to Africa and possible re-enslavement. Murray, Odious Commerce, pp. 27I-297; Roldán de Montaud, “Origen, evolución, y supresión”, pp. 574-576; Luis Martínez-Fernández, “The Havana Anglo-Spanish Mixed Commission”, Slavery E Abolition, I6:2 (1995), pp. 209-2 I 3.

49. La Rosa Corzo, Los cimarrones, p. 68.

50. AHN, Ultramar, leg. 37 , exp. I, no. 30 (26 July I 837 ).

5. Naranjo Orovio, "La amenaza haitiana", pp. 83-178.

52. “Acuerdo. En Sesión de la Rl. Junta de fomento..." (5 August I 835 ), reproduced and transcribed in Berta Alfonso Ballol et al., El Camino de Hierro de la Habana a Güines: Primer ferrocarril de Iberoamérica (Madrid, I987), p. 78.

53. "List of Mechanicks Laborers \& Overseers employed for the real Junta de Fomento of the Island of Cuba - Dispatched by brig Havre to Havana Nov I, I 835 ", reproduced and transcribed in Ballol et al., El Camino de Hierro, p. 80. 
Another contractor, named Erastus Denison, was hired by the Junta because he had shown his knowledge of the "construction and use of machinery in general, in the construction of works in the water, in all branches of common works of mechanics, including steam machines and locomotives". He would be paid i Io pesos per month for at least six months, though the contract could be extended to one year. ${ }^{54}$

Those who contracted to go to Cuba as peones and operarios (unskilled workers) were to be paid only twenty-five pesos per month, though this wage was almost double or more than the wages offered to any of the other groups of the unskilled. Those laborers working with explosives would be offered "something more". The contracts were for six months but could be extended to one year at the discretion of their employer. The Junta would provide shelter, but all other maintenance would be at the expense of the workers. Their contracts also required them to pay back the costs of their passage and provisions for the voyage through deductions from their wages. The Junta clearly had high hopes that this white, largely Anglophone cohort would prove to be exemplary workers, with some knowledge of either canal or railroad building, at a relatively modest cost. ${ }^{55}$

In Cuba these contracted workers from North America were called irlandeses, "Irish", although there were some other nationalities in the group. There are varying estimates of the size of this group. British abolitionist David Turnbull, who visited Cuba in 1837 , reported that "upwards of a thousand Irishmen" came to work on the railroad. Margaret Brehony has confirmed Turnbull's guess, estimating between 800 and I,200 irlandeses in the cohort that built the Havana to Güines rail line. ${ }^{56}$

The irlandeses began arriving in November 1835 . Even though their pay was high by Cuban standards, some were already heavily indebted to the Junta before leaving New York, meaning that their first few months in Cuba would have been lean indeed. ${ }^{57}$ By spring of 1836 , some of the irlandeses had returned home; some had deserted the railroad sites, but did not

54. "Contratas", n.d., reproduced and transcribed in Ballol et al., El Camino de Hierro, p. 8 . 55. Ibid. There are many parallels in the genesis, financing, management (especially the resort to contractors), and labor recruitment and exploitation between this analysis of railroad building in Cuba and canal building in North America over a similar period. See Peter Way, Common Labour: Workers and the Digging of North American Canals, I780-I860 (Cambridge, 1993). There were direct connections as well. Benjamin Wright was one of three head engineers on the building of the Erie Canal and other North American projects. His son, Benjamin $\mathrm{H}$. Wright, recruited the first groups of irlandeses for the construction of the first rail line in Cuba. Ibid., pp. 56-57.

56. David Turnbull, Travels in the West: Cuba; with Notices of Porto Rico and the Slave Trade (London, I840), p. I90; Margaret Brehony, "Irish Migration to Cuba, I835-1845: Empire, Ethnicity, Slavery, and 'Free' Labour” (Ph.D., National University of Ireland, Galway, 20I2),

p. 35 .

57. Brehony, "Irish Migration to Cuba", pp. $35-36$. 
have the resources to book a return passage. Both the American and the British consuls received pleas from destitute workers from North America for help paying for a passport and passage back home. The American consul Nicholas Trist reported paying sixty dollars to a young woman, who had come to Cuba with her husband, to help her return via New Orleans with her two young children. ${ }^{58}$

The Junta decided that their resort to North American contract laborers, at least the unskilled peones, was too expensive and created problems even after the workers had left the rail works. The chief engineer Cruger blamed the workers themselves, angered by what he called their "drunken state", insubordination, disobedience, and complaints about low pay and work conditions. He thought any who were unhappy could go back to the US "at their own expense". 59

The irlandeses were a short-lived experiment with indenture that helped advance the first railroad line only briefly and revealed some of the dangers of importing culturally alien workers who could not be subjected to the lash and shackles, as were the enslaved and prisoners. The irlandeses resisted through drink, disobedience, and desertion. Since the state refused to pay for their return to the US or allow them to work on their own account elsewhere, some of them appeared idle and destitute in the streets of Havana after their contracts were completed.

The Junta de Fomento initiated another experiment with contract labor within the Spanish Empire that succeeded in recruiting a similar number of workers as the North American venture, but at a lower cost and with more control. In I 835 , the Junta contracted several Spanish ship captains to recruit bonded laborers in the Canary Islands for work on the rail line. One contract with Captain Nicolás Domínguez in April I836 stipulated that the captain would be paid up to forty-five pesos for the passage and passport or license of each worker. Those contracted had to be between twenty and forty years old and "apt to be employed" in building the railroad. The workers had to agree to be employed in the rail works or on another Junta project at least long enough to pay back the costs of their passage, paying three pesos per month until the debt was cleared. They would be paid nine pesos per month and provided with shelter, food, and medical care for up to one year. Though the Canary Islanders, called isleños in Cuba, received some maintenance, unlike the irlandeses, their pay was even less than the wage offered to hired slaves. These workers also had to agree not to desert the rail works before covering the costs of their passage, under penalty of a hefty fine of twenty-four pesos, plus the cost of their

59. Quoted in ibid., p. 5 I. 
apprehension. ${ }^{60}$ This strategy produced the largest group of contract laborers for the first rail project, a total of 927 Canary Islanders. However, by the time the rail line opened two years later in 1837 , only seven remained working on the railroad, in part due to the miserable conditions under which they labored. One hundred and fifty-six of the Canary Islanders had died, another thirty-five were incapacitated, and eighty-four had fled the rail works. ${ }^{6 \mathrm{I}}$

Some of the Canary Islanders tried to remedy what they saw as ill treatment by complaining to authorities that they were not paid regularly and were given disgusting food. Some protested with sticks and knives about their miserable living and working conditions. In both cases their complaints were either ignored or repressed. To the charges of late pay and rotten food, the Junta countered that their contracts did not stipulate when exactly they would be paid and that the isleños only ate cornmeal and fish at home, so the food in Cuba was sufficient. In response to the more vigorous armed resistance, the Intendant the Count of Villanueva ordered that the protesters who were apprehended be sent back to the rail project in chains for two months. ${ }^{62}$

It is not surprising, therefore, that the contracted Canary Islanders suffered high rates of death and frequently tried to flee the rail works. Death and desertion among them rose to almost twenty-six per cent over two years. When added to those workers who were incapacitated, the Junta's losses rose to almost thirty per cent. The Junta was particularly concerned about desertion among the Canary Islanders, since they could easily blend into the larger Hispano-Cuban population. The Junta tried to impose high fines on anyone who might harbor a fugitive worker. Most of the isleños would have been fluent in Spanish and, as the Junta reported, there were "sound reasons to fear that they might desert, favored by the multitude of persons of the same origin who were well established on the island". ${ }^{3}$

Both schemes for white immigration from the United States and the Canaries were bedeviled by high mortality and desertion, a testimony to the difficult and unhealthy conditions under which these workers labored. Still, their work ultimately may have ensured the successful completion of the first rail line, extending opportunities for successful plantation expansion far beyond the port of Havana to the south and east. ${ }^{64}$

60. Antonio de Escovedo, "Condiciones del contrato para el embarque de operarios procedentes de Islas Canarias entre la Real Junta de Fomento y el Sr. Nicolás Domínguez, 30 April I 836 ”, reproduced and transcribed in Ballol et al., El Camino de Hierro, p. 84.

6r. AHN, Ultramar, leg. 37, exp. I, no. 29.

62. Violeta Serrano, Crónicas del primer ferrocarril de Cuba (Havana, I973), p. 36.

63. Quoted in Oscar Zanetti and Alejandro García, Sugar and Railroads, A Cuban History, I837-1959, trans Franklin W. Knight and Mary Todd (Chapel Hill, NC, 1998), p. 29; Serrano, Crónicas, p. 36.

64. Zanetti and García, Sugar and Railroads, pp. I 17-i i 8. However, according to Zanetti and García the Junta had greater success importing labor when they began bringing in Chinese contract laborers in 1847 , p. I 21 . 
By 30 June 1837 , the total number of workers on the rail line was 742 men; only seven of the contracted isleños continued working on the railroad. Various contingents of enslaved and recently freed men of African descent remained, almost sixty-five per cent of the total workforce - eighty-seven emancipados diverted by the Junta from work on Havana's aqueduct, I45 of the Junta's own slaves, and between 200 and 250 of the Junta's fugitive slaves. The remaining workers were employed by the various contractors in transport of materials, stone work, and excavation, though the Junta did not keep track of their numbers or fortunes. ${ }^{65}$

After one year of extensive use of contract workers on the railroad project, the Junta returned to using mostly enslaved workers from among those at its disposal. Similar to the hasty purchase of large numbers of state slaves in the defense works of the I760s, the Junta's recruitment of European, North American, and Canary Island contract workers provided the surge of coerced labor that the project needed to initiate rail construction. The costs and problems encountered with the resort to thousands of kings' slaves in the $1760 \mathrm{~s}$ and hundreds of contract workers in the I830s encouraged the return to employment of coerced workers whose recruitment did not involve major investments and over whom the projects' supervisors had significant control. In the case of the first rail line, slaves, some owned by the Junta and some captured in flight from their owners, came at lower cost and could be more easily controlled, due to their unfree status.

The contracting of white laborers for plantation work would not be the long-term answer to the vagaries of the illegal slave trade to Cuba. Indentured Canary Islanders, especially, could desert too easily due to their whiteness and Spanish language. Similar to other Caribbean plantation colonies in the mid-nineteenth century, Cuban elites and officials eventually turned their attention to Asia and Mexico for laborers perceived as racially different enough to provide low-cost, bound labor on plantations. Funds were invested in the immigration of yucatecos (largely Mayans or mestizos from the Yucatan peninsula) and Chinese as indentured laborers, whose contracts obligated them to accept wages well below the Cuban norm for both free wage earners and hired slaves. ${ }^{66}$ The prices that planters paid to purchase their contracts were also considerably lower than the prices for African slaves; from I 845 to I 860 prices for Chinese indentures were less than half those of slaves. ${ }^{67}$ Though the numbers of yucatecos imported into Cuba were small, Chinese indentured laborers arrived in much larger numbers,

65. "Cuadro del camino de hierro de la ciudad de la Habana a la villa de Güines en 30 de Junio de I837”, AHN, Ultramar, 37, exp. I, no. 29.

66. Naranjo Orovio, "Amenaza", p. I62.

67. Lisa Yun, The Coolie Speaks: Chinese Indentured Laborers and African Slaves in Cuba

(Philadelphia, PA, 2008), Table i.2, p. I7. 


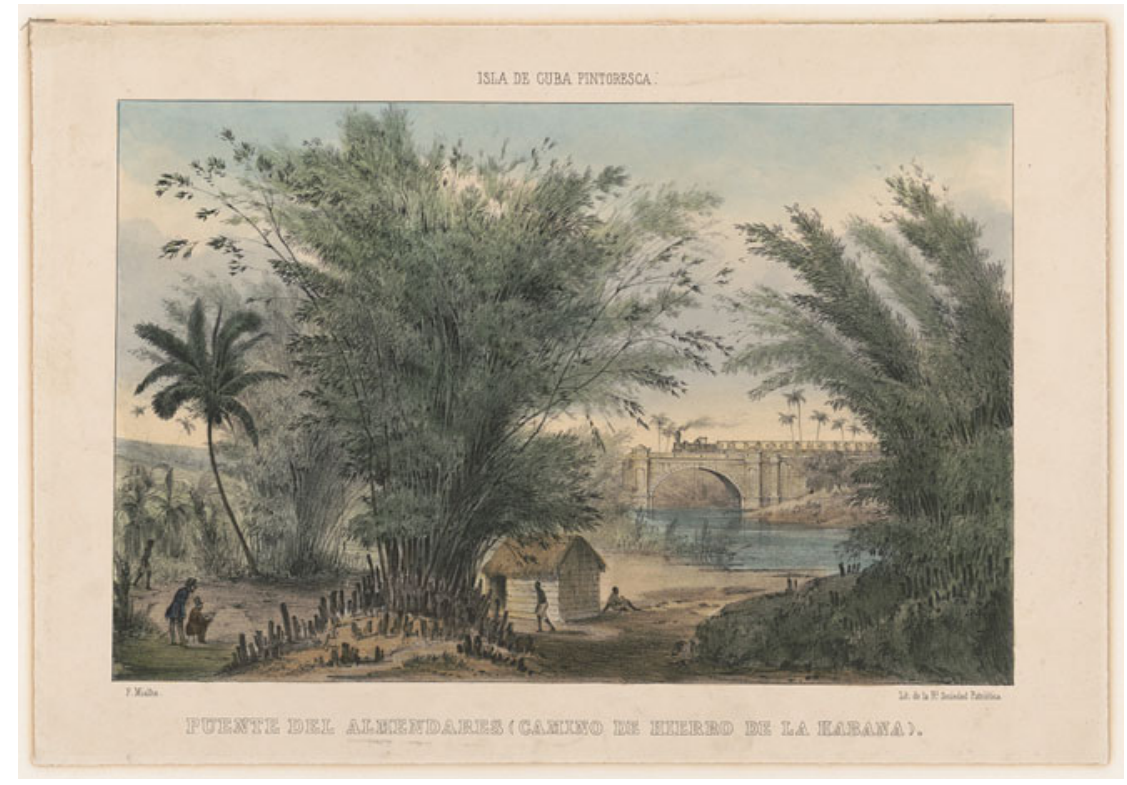

Figure 2. Railroad Bridge over the Almendares River near Havana.

Library of Congress Prints and Photographs Division, Washington D.C., USA.

over I 20,000 from I 847 to $1874 .{ }^{68}$ Conditions for these contract workers were so terrible that the governments of their home countries ultimately curtailed their trade to Cuba. ${ }^{69}$

68. Ibid., p. I9, Table I.3, cites 138,156 Chinese as having embarked from China to Cuba from I $847-1873$, and I 21,8 Io who actually landed. Estimates of yucateco migrants imported to Cuba vary widely, from 730 to as many as 10,000, but even the highest number was small compared to African- and even Chinese-bound immigrants. See Paul Estrade, "Los colonos yucatecos como sustitutos de los esclavos negros", in Consuelo Naranjo Orovio and Tomás Mallo Gutiérrez (eds), Cuba la perla de las Antillas: Actas de las I Jornadas sobre "Cuba y su historia" (Madrid, 1994), p. 97. Yaremko, Indigenous Passages, pp. I I 5-I I 8. Many were captured and sold to Cuban traders by Mexican officials during the Caste Wars in the Yucatan in the I840s. See Nelson A. Reed, The Caste War of Yucatán (Stanford, CA, 200I), p. I42; Yaremko, Indigenous Passages, pp. 92-118, on migration, both forced and free, from the Yucatan to Cuba from the sixteenth to the nineteenth centuries.

69. For more detail on the contract laborers from Yucatan and China, see Evelyn P. Jennings, “Some Unhappy Indians Trafficked by Force': Race, Status and Work Discipline in Mid-Nineteenth Century Cuba", in Raphael Hörmann and Gesa Mackenthun (eds), Human Bondage in the Cultural Contact Zone (Münster, 2010), pp. 209-225. On conditions for Chinese contract workers in Cuba, in addition to Yun, The Coolie Speaks, see Denise Helly, "Introduction", The Cuba Commission Report: A Hidden History of the Chinese in Cuba (Baltimore, MD, I993), pp. 2 I-27; and the transcript of the Commission's Report. 


\section{CONCLUSION}

This examination of forced labor in road and railroad construction reveals several insights about the state's use of coercion for public works to connect Havana's port with the rapidly expanding plantation sector in its hinterland. The vast majority of workers employed in infrastructure building in Cuba entered through the port of Havana as migrants under some form of coercion - enslavement, a prison term at hard labor, or, after I 800 , an indenture contract. As the island's plantation boom took place parallel to the growing movement to abolish the transatlantic slave trade and slavery itself, for state officials the costs of purchasing enslaved workers rose prohibitively over much of the period from $1790-1838$. State- or privately owned slaves were usually too valuable to be employed in large numbers in public works. Hence, Cuban elites and their state collaborators sought out other vulnerable groups who could be forced to do road and rail work at lower costs and under sufficient control to advance the projects.

Free householders successfully rebuffed those efforts. Convicts had little choice, but their numbers and lengths of sentence fluctuated widely. Captured fugitive slaves rarely provided years of labor for public projects, because they were often in poor health when captured and their owners were likely to reclaim them. State officials and Cuban planters had more success, forcing the unfortunate emancipados into both public works and plantation labor, because the anti-slave trade treaties allowed Cuban captains general to consign them for years of coerced labor, in spite of their nominally free status.

Ultimately, contract laborers provided the mix of low cost and unfreedom that both planters and state officials desired, after some experimentation. Unlike free workers, contract laborers' resistance or desertion could result in arrest and return to work as a convict, but the racial hierarchy of a plantation society set both state and private employers' expectations for necessary subservience. "Irish" workers, whose whiteness was initially seen as an asset, were ultimately deemed too disobedient and their recruitment was abandoned. Canary Islanders were white and Hispanophone and therefore too likely to successfully flee work sites.

These problems were outweighed in the short term as the contracted labor of North Americans and Europeans was the supplement to other forms of forced labor needed to establish the first rail connection between Havana's port and growing plantations to the south and east. However, after 1838 , both planters and colonial officials sought a new group of racially and culturally different contract workers, especially from China, to supplement enslavement on plantations and on rail lines, as the fate of slavery in the Atlantic world became more uncertain. The railroad promoters' problems and losses with white contract workers in the early i830s led Cuban Captain General Alcoy in 1849 to petition the Crown for permission to 
use the tools of enslavement to control contracted workers from Yucatan and China - "the whip, shackles, and stocks". Queen Isabella II agreed that such control was essential because without them "the subordination of the African race so indispensable for the tranquility of [Cuba] would be altered".$^{\circ}$ The experiments with white contract workers showed state officials and planters that coerced labor without the controls allowed by enslavement were too risky in Cuba once the sugar boom and slavery dominated the island's economy and society. 